DOI: $10.19195 / 2084-5065.39 .10$

\title{
Problematyka przemocy w rodzinie w świetle wybranych uregulowań międzynarodowych
}

\author{
AGNIESZKA OLSZEWSKA \\ Instytut Nauk Prawnych PAN
}

Przemoc w rodzinie jest zjawiskiem wielowymiarowym, o którym możemy mówić w ujęciu społecznym, psychologicznym i prawnym. Według T. Hobbesa w naturze człowieka odnaleźć można trzy podstawowe przyczyny nieporozumień: rywalizację, nieufność i żądzę sławy ${ }^{1}$. Źródłem przemocy jest agresja. Według T. Tomaszewskiego agresja to „zachowanie się skierowane przeciw komuś lub czemuś. Może mieć dwa kierunki: na zewnątrz, przeciw przedmiotom lub osobom zewnętrznym, na przykład przeciw samej przeszkodzie, lub osobie będącej sprawcą trudności albo przeciw sobie samemu”2. J. Ranschburg uważa, że ,agresja to każde zamierzone działanie w formie otwartej lub symbolicznej, mające na celu wyrządzenie komuś lub czemuś szkody, straty lub bólu"3.

Szczególnym rodzajem przemocy jest przemoc w rodzinie. Według definicji Światowej Organizacji Zdrowia z 1996 r. przemoc jest

celowym użyciem siły fizycznej lub władzy, sformułowanym jako groźba lub rzeczywiście użytym, skierowanym przeciwko samemu sobie, innej osobie, grupie lub społeczności, które albo prowadzi do albo z którym wiąże się wysokie prawdopo-

1 T. Hobbes, Lewiatan, przeł. C. Znamierowski, Warszawa 1954, s. 210.

2 T. Tomaszewski, Wstę do psychologii, Warszawa 1963, s.138.

3 J. Ransburg, Lęk, gniew, agresja, Warszawa 1980, s. 77. 
dobieństwo spowodowania obrażeń cielesnych, śmierci, szkód psychologicznych, wad rozwoju lub braku elementów niezbędnych do normalnego życia i zdrowia ${ }^{4}$.

J. Mellibruda uważa, że

przemoc to działania lub rażące zaniedbania dokonywane przez jednego z członków rodziny przeciwko pozostałym, wykorzystujące istniejącą lub stworzoną przez okoliczności przewagę sił lub władzy i powodujące u ich ofiar szkody lub cierpienie godzące w ich prawa lub dobra osobiste, a w szczególności w ich życie lub zdrowie (fizyczne lub psychiczne) $)^{5}$.

Jak wskazuje K. Motyka, niektórzy badacze dopatrują się międzynarodowej ochrony praw człowieka już w XIII w. przed Chrystusem, traktując jako swoiste prawo człowieka do azylu terytorialnego w traktatach zawieranych z sąsiadami przez władców imperium Hetytów ${ }^{6}$. Kodeks Hammurabiego stanowił, że władza króla jest ustanowiona w celu strzeżenia sprawiedliwości i w celu ochrony słabych przed złymi uczynkami silnych ${ }^{7}$. Sofiści greccy i stoicy jako pierwsi głosili naturalną wolność i równość ludzi, a także wyższość praw naturalnych nad prawem stanowionym $^{8}$. Poza tymi starożytnymi aktami prawnymi i myślami filozoficznymi jako początek bytu praw człowieka w prawie międzynarodowym uważa się zawierane od XVI wieku traktaty gwarantujące niektórym mniejszościom narodowym wolność religijną. Na pierwszym miejscu wymieniany jest pokój w Augsburgu z 1555 roku, który wprowadził wprawdzie zasadę cuius regio, eius religio (poddani musieli przyjać wyznanie swego pana), jednakże w miastach utrzymano wolność religijną. W XIX i XX wieku miało miejsce wiele interwencji w suwerenność państw w celu ochrony mniejszości, głównie chrześcijańskich

${ }^{4}$ WHO - Global status report on violence prevention 2014, Part 1 - Background, 1996 Violence Definition, p. 2; pol. WHO - Sprawozdanie na temat globalnej sytuacji w dziedzinie zapobiegania przemocy, Część 1 Podstawy, Definicja przemocy z roku 1996, s. 2.

5 J. Mellibruda, Wybrane problemy patologii zycia rodzinnego, [w:] Psychologia. Podręcznik akademicki. Jednostka w spoteczeństwie i elementy psychologii stosowanej, Gdańsk 2002, s. 755.

${ }^{6}$ K. Motyka, Prawa człowieka. Wprowadzenie. Wybór źródet, Lublin 2004, s. 33.

7 M. Stępień, Kodeks Hammurabiego, wersja komputerowa dostępna wraz ze wstępem na: www.zrodla.historyczne.prv.pl (dostęp: 15.01.2016).

${ }^{8}$ R. Kuźniar, Prawa człowieka. Prawo, instytucje, stosunki międzynarodowe, Fundacja Studiów Międzynarodowych, Warszawa 2004, s. 10-14. 
mniejszości religijnych w Turcji — za myśl przewodnią mając idee Grocjusza odnoszące się do konieczności odstępstwa od zasady suwerenności państw w szczególnych przypadkach ${ }^{9}$.

Działania na rzecz ochrony praw człowieka (bez używania tego terminu) były prowadzone także przez Międzynarodowy Komitet Czerwonego Krzyża. Począwszy od 1864 roku powstawały tzw. konwencje genewskie $^{10}$, które tworzyły międzynarodowe prawo humanitarne konfliktów zbrojnych. Szczególny i największy wzrost znaczenia praw człowieka datowany jest na okres po II wojnie światowej ${ }^{11}$. Od uchwalenia w dniu 10 grudnia 1948 roku przez Zgromadzenie Ogólne Narodów Zjednoczonych Powszechnej Deklaracji Praw Człowieka przyjętych zostało około stu różnych konwencji, protokołów i innych dokumentów międzynarodowych mających zarówno uniwersalny, jak i regionalny charakter. Według R. Kuźniara ochrona praw człowieka „stała się przedmiotem polityki państw, aktywności ruchów społecznych, w tym coraz liczniejszych i potężniejszych organizacji pozarządowych, doktryny i nauczania kościołów chrześcijańskich" 12 .

Wszelkie zagadnienia odnoszące się do praw kobiet, dzieci i przemocy w rodzinie zawierają się $\mathrm{w}$ wielu konkretnych prawach człowieka, do których zaliczyć należy w szczególności: prawo do równego korzystania ze wszystkich praw człowieka i podstawowych wolności; zwalczanie dyskryminacji; prawo do życia; wolność od tortur, okrutnego, nieludzkiego i poniżającego traktowania lub karania; wolność od niewolnictwa, poddaństwa i pracy przymusowej; prawo do wolności osobistej i bezpieczeństwa; prawo do prywatności; wolność myśli, sumienia, religii i prze-

9 K. Motyka, op. cit., s. 34.

10 Uchwalonych zostało 8 Konwencji i 3 Protokoły Dodatkowe. Pierwsza Konwencja pochodzi z 22 sierpnia 1864 roku, druga z 6 lipca 1906 roku, trzecia i czwarta Konwencja (trzecia - o polepszaniu losu chorych i rannych w armiach czynnych, czwarta — dotycząca traktowania jeńców wojennych) — obie z dnia 27 lipca 1929 roku. W dniu 19 sierpnia 1949 roku zostały podpisane kolejne 4 Konwencje (dotyczące polepszenia losu rannych i chorych w armiach czynnych na lądzie, polepszenia losu rannych, chorych i rozbitków sił zbrojnych na morzu, traktowania i ochrony osób cywilnych podczas wojny). Do tych ostatnich Konwencji podpisane zostały trzy Protokoły dodatkowe — dwa w 1977 roku i jeden w roku 2005.

11 Ibidem, s. 36.

12 R. Kuźniar, op. cit., s. 10-14. 
konań; prawo do posiadania opinii i do jej wyrażania; prawo mężczyzny i kobiety do zawarcia małżeństwa i założenia rodziny.

Funkcjonujące na świecie rozwiązania odnoszące się zarówno do równouprawnienia kobiet, jak i konkretnie do zagadnień związanych z przemocą $\mathrm{w}$ rodzinie różnią się obszarem obowiązywania, a także zakresem skuteczności wobec innych państw na arenie międzynarodowej. $Z$ tego punktu widzenia za właściwy uznałam podział na praktykę Narodów Zjednoczonych, Rady Europy oraz Unii Europejskiej.

\section{Prawa kobiet w praktyce Narodów Zjednoczonych}

Organizacja Narodów Zjednoczonych powstała 26 czerwca 1945 roku na konferencji międzynarodowej w San Francisco. Statut ONZ odzwierciedlał przekonanie, że jednym z naczelnych warunków utrzymania pokoju i dążenia do postępu jest skuteczna, międzynarodowa ochrona praw człowieka. Konferencja założycielska NZ, która odbyła się w San Francisco, nie doprowadziła do zdefiniowania praw człowieka i sformułowania ich katalogu, jednak karta założycielska NZ stała się doskonałym punktem wyjścia dla rozwoju instytucji i prawa międzynarodowego w obszarze praw człowieka ${ }^{13}$.

Jednym z pierwszych dokumentów odnoszących się do ochrony praw kobiet była Międzynarodowa Konwencja o zwalczaniu handlu kobietami i dziećmi podpisana w Genewie 30 września 1921 roku $^{14}$. Zgodnie z jej treścią państwa-strony zobowiązane są do podejmowania wszelkich środków mających na celu ściganie i karanie osób zajmujących się handlem dziećmi, a także niezbędnych do ukarania usiłowań przekroczenia i przygotowania czynów karalnych, o jakich mowa w art. 1 i 2 Międzynarodowej Konwencji z dnia 4 maja 1910 roku, podpisanej w Paryżu, dotyczącej zwalczania handlu żywym towarem ${ }^{15}$.

13 Ibidem, s. 62-63.

14 Międzynarodowa Konwencja o zwalczaniu handlu kobietami i dziećmi podpisana w Genewie 30 września 1921 r., ratyfikowana zgodnie z ustawą z dnia 13 lutego 1924 r. — Dz.U. R.P. Nr 20, poz. 211, Dz.U. z 1925 r. Nr 125, poz. 893.

15 Międzynarodowa Konwencja z dnia 4 maja 1910 r., podpisana w Paryżu, dotycząca zwalczania handlu żywym towarem. Rząd Polski zgłosił w dniu 12 stycznia 1921 r. swoje przystąpienie do Międzynarodowego Porozumienia z dnia 18 maja 1904 r. i do 
Najważniejszym dokumentem międzynarodowym traktującym o równości płci jest Powszechna Deklaracja Praw Człowieka ${ }^{16}$, która została uchwalona 10 grudnia 1948 roku przez Zgromadzenie Ogólne NZ. W Deklaracji wyróżnione zostały trzy grupy praw i wolności. Po pierwsze prawa i wolności osobiste, obejmujące w szczególności prawo do życia, wolności i bezpieczeństwa. Drugą grupą są prawa i wolności publiczne, w szczególności prawo do obywatelstwa i wolności słowa. Należy wskazać także prawa ekonomiczne, socjalne i kulturalne, przede wszystkim prawo do pracy, do słusznego wynagradzania za pracę, do urlopu i wypoczynku, do godziwego poziomu życia oraz do opieki lekarskiej ${ }^{17}$.

W kwestii dyskryminacji kobiet ważną rolę odgrywa Konwencja Międzynarodowej Organizacji Pracy dotycząca jednakowego wynagrodzenia dla pracujących mężczyzn i kobiet za prace jednakowej wartości, przyjęta w Genewie dnia 29 czerwca 1951 r. ${ }^{18}$ Zgodnie z art. 2 wspomnianej Konwencji każdy Członek Międzynarodowej Organizacji Pracy powinien ją popierać za pomocą środków dostosowanych do obowiązujących metod ustalania stawek wynagrodzenia i, o ile jest to zgodne z tymi metodami, zapewniać stosowanie do wszystkich pracowników zasady jednakowego wynagrodzenia pracujących kobiet i mężczyzn za pracę jednakowej wartości. Zasada ta będzie mogła być stosowana za pomocą: bądź ustawodawstwa krajowego, bądź wszelkiego systemu ustalania wynagrodzenia określonego lub uznanego przez ustawodawstwo, bądź układów zbiorowych zawartych pomiędzy pracodawcami a pracownikami, bądź przez połączenie tych różnych sposobów ${ }^{19}$.

Międzynarodowej Konwencji z dnia 4 maja 1910 r. wraz z uzupełniającym ją protokołem zamknięcia z dnia 4 maja 1910 r., podpisanych w Paryżu, dotyczących zwalczania handlu żywym towarem. Fakt ten ogłoszono w Oświadczeniu Rządowym z dnia 8 września 1922 r. Porozumienie i Konwencja zostały ogłoszone w Dz.U. z 1922 r. Nr 87, poz. 783, sprostowane w Dz.U. z 1929 r. Nr 62, poz. 487.

16 Powszechna deklaracja praw człowieka przyjęta i proklamowana rezolucją Zgromadzenia Ogólnego ONZ 217 A (III) w dniu 10 grudnia 1948 r.

17 R. Kuźniar, op. cit., s. 63-66.

18 Konwencja nr 100 Międzynarodowej Organizacji Pracy dotycząca jednakowego wynagrodzenia dla pracujących mężczyzn i kobiet za pracę jednakowej wartości, przyjęta w Genewie dnia 29 czerwca 1951 r. (Dz.U. z 1955 r. Nr 38, poz. 238).

19 Art. 2 Konwencji nr 100 Międzynarodowej Organizacji Pracy dotyczącej jednakowego wynagrodzenia dla pracujących mężczyzn i kobiet za pracę jednakowej wartości. 
Konwencja Nr 111 Międzynarodowej Organizacji Pracy, przyjęta w Genewie dnia 25 czerwca 1958 r. $^{20}$, odnosząca się do dyskryminacji w zatrudnianiu i wykonywania zawodu, jest podstawą uregulowań prawnych zwalczających dyskryminację kobiet na rynku pracy ze względu na płeć. Zgodnie z przepisami tej Konwencji pojęcie „,dyskryminacja" zdefiniowano jako wszelkie rozróżnienie, wyłączenie lub uprzywilejowanie oparte na rasie, kolorze skóry, płci, religii, poglądach politycznych, pochodzeniu narodowym lub społecznym, które powoduje zniweczenie albo naruszenie równości szans lub traktowania $\mathrm{w}$ zakresie zatrudnienia lub wykonywania zawodu, a także wszelkie inne rozróżnienie, wyłączenie lub uprzywilejowanie powodujące zniweczenie albo naruszenie równości szans lub traktowania w zakresie zatrudnienia lub wykonywania zawodu, które będzie mogło być wymienione przez zainteresowanego Członka MOP po zasięgnięciu opinii reprezentatywnych organizacji pracodawców i pracowników, o ile takie istnieją, oraz innych właściwych organizacji. Dla celów Konwencji wyrazy „zatrudnienie" i ,zawód” obejmują dostęp do szkolenia zawodowego, dostęp do zatrudnienia i do poszczególnych zawodów, jak również warunki pracy ${ }^{21}$.

Konwencja ONZ w sprawie zwalczania dyskryminacji w dziedzinie oświaty, sporządzona w Paryżu dnia 15 grudnia 1960 roku $^{22}$, która została przyjęta przez Konferencję Ogólną UNESCO, umożliwia kobietom i dziewczętom równy dostęp do edukacji i zakazuje dyskryminacji w dziedzinie oświaty ${ }^{23}$. W rozumieniu Konwencji przez „dyskryminację" należy rozumieć wszelkiego rodzaju wyróżnianie, wykluczanie, ograniczanie lub uprzywilejowanie ze względu na rasę, kolor skóry, płeć, język, wyznanie, przekonania polityczne lub jakiekolwiek

${ }^{20}$ Konwencja Nr 111 Międzynarodowej Organizacji Pracy dotycząca dyskryminacji w zakresie zatrudnienia i wykonywania zawodu, przyjęta w Genewie dnia 25 czerwca 1958 r. (Dz.U. z 1961 r. Nr 62, poz. 218)

21 Art. 1.1 i 1.3 Konwencji Nr 111 Międzynarodowej Organizacji Pracy dotycząca dyskryminacji w zakresie zatrudnienia i wykonywania zawodu.

22 Konwencja ONZ w sprawie zwalczania dyskryminacji w dziedzinie oświaty, sporządzona w Paryżu dnia 15 grudnia 1960 r. (Dz.U. z 1964 r. Nr 40, poz. 268), weszła w życie dnia 15 grudnia 1964 r.

${ }^{23}$ Postęp dla wszystkich. Równe prawa, równe szanse dla kobiet i mężczyzn - Materiały Informacyjne Ośrodka Badań ONZ w Warszawie, luty 2010, s. 12. 
inne, narodowość lub pochodzenie społeczne, sytuację materialną lub urodzenie, które ma na celu albo którego skutkiem jest przekreślenie lub naruszenie zasady jednakowego traktowania w dziedzinie oświaty, a w szczególności zamknięcie dostępu jakiejkolwiek jednostce lub grupie osób do oświaty jakiegokolwiek stopnia lub typu, ograniczenie dla jakiejkolwiek osoby lub grupy osób oświaty do niższego jej stopnia, utworzenie lub utrzymywanie oddzielnych systemów oświatowych lub zakładów nauczania dla jakichkolwiek osób lub grup osób, poza przypadkami przewidzianymi w artykule 2 niniejszej Konwencji, albo stawianie jakiejkolwiek osoby lub grupy osób w sytuacji nie dającej się pogodzić z godnością człowieka ${ }^{24}$.

Konwencja ONZ w sprawie likwidacji wszelkich form dyskryminacji kobiet z 1979 roku $^{25}$ uznawana jest za międzynarodową kartę praw kobiet. Konwencja wyraźnie zabrania różnicowania, ograniczania bądź wykluczania ze względu na płeć. Dokument ten zakłada, że tradycyjne role kobiet i mężczyzn w rodzinie oraz społeczeństwie muszą ulegać ewolucji, aby równe traktowanie kobiet i mężczyzn było możliwe ${ }^{26}$. Zgodnie z przepisami Konwencji pojęcie „dyskryminacja kobiet” oznacza wszelkiego rodzaju różnicowanie, wyłączenie lub ograniczenie ze względu na płeć, powodujące lub mające na celu uszczuplenie albo uniemożliwienie kobietom przyznania, realizacji bądź korzystania na równi z mężczyznami z praw człowieka oraz podstawowych wolności w dziedzinach życia politycznego, gospodarczego, społecznego, kulturalnego, obywatelskiego i innych - niezależnie od ich stanu cywilnego ${ }^{27}$.

Doniosłe znaczenie w dziedzinie ochrony praw kobiet ma Deklaracja o eliminacji przemocy wobec kobiet $^{28}$. Deklaracja uznaje przemoc wobec kobiet za jeden z mechanizmów, który uniemożliwia kobietom

${ }^{24}$ Art. 1 Konwencji w sprawie zwalczania dyskryminacji w dziedzinie oświaty.

${ }^{25}$ Konwencja ONZ w sprawie likwidacji wszelkich form dyskryminacji kobiet przyjęta przez Zgromadzenie Ogólne ONZ 18 grudnia 1979 r, obowiązująca od 3 września 1981 r. Polska ratyfikowała Konwencję (Dz.U. z 1982 r. Nr 10, poz. 71) oraz protokół dodatkowy (Dz.U. z 2003 r. Nr 41, poz. 343).

26 A. Łopatka, Międzynarodowe prawo praw człowieka, Warszawa 1998, s. 86-87.

27 Art. 1 Konwencji ONZ w sprawie likwidacji wszelkich form dyskryminacji kobiet.

28 Deklaracja o Eliminacji Przemocy wobec Kobiet uchwalona przez Zgromadzenie Ogólne Narodów Zjednoczonych — Rezolucja Zgromadzenia Ogólnego ONZ 48/104 z dnia 20 grudnia 1993. 
pełne uczestnictwo we wszystkich aspektach życia. Jako przejaw przemocy wobec kobiet Deklaracja wymienia: fizyczna, seksualną i psychiczną przemoc występującą w rodzinie; maltretowanie, wykorzystywanie seksualne dzieci w domu rodzinnym; przemoc związaną z obowiązkiem wniesienia posagu; gwałt małżeński; okaleczanie genitalne kobiet oraz inne tradycyjne praktyki szkodliwe dla kobiet; przemoc w związkach pozamałżeńskich; fizyczna, seksualną i psychiczną przemoc o charakterze społecznym, do której zalicza się gwałt, molestowanie seksualne, wykorzystywanie seksualne i zastraszanie w miejscu pracy, placówkach edukacyjnych i innych miejscach publicznych; handel kobietami i zmuszanie do prostytucji ${ }^{29}$.

Pierwsza Światowa Konferencja w sprawach Kobiet miała miejsce w Meksyku w 1975 roku. W raporcie końcowym Konferencji podkreślono, że stała się ona ,początkiem międzynarodowych starań na rzecz naprawienia tego, co w historii złe". Głównym celem Konferencji było wzmocnienie działań na rzecz promowania równości kobiet i mężczyzn. Na Konferencji przyjęty został Światowy Plan Działań dotyczący wprowadzenia w życie celów Międzynarodowego Roku Kobiet. Proklamowana również została Dekada ONZ na rzecz Kobiet w latach 1976-198530.

Druga Światowa Konferencja w sprawach Kobiet miała miejsce w Kopenhadze w 1980 r. Podczas Konferencji oceniony został postęp, jaki nastąpił w pierwszej połowie Dekady Kobiet. Przyjęty został także Program Działania na Drugą Połowę ONZ-towskiej Dekady Kobiet pod hasłem „Równość, Rozwój i Pokój”. Głównym założeniem tego programu była identyfikacja działań, które powinny zostać podjęte na rzecz podniesienia statusu kobiet ${ }^{31}$.

Trzecia Światowa Konferencja w sprawach Kobiet odbyła się w Nairobi w 1985 r. W trakcie tej Konferencji podsumowane zostały osiagnięcia Dekady Kobiet, przyjęty został także dokument końcowy zatytułowany „Strategie Długoterminowe na rzecz Podniesienia Statusu Kobiet”. Strategie te zakładały przyśpieszenie zmian politycznych oraz legislacyjnych uwzględniających prawa kobiet w większym stopniu. Za zagadnienia

29 Art. 2 Deklaracji o Eliminacji Przemocy wobec Kobiet.

30 Postęp dla wszystkich...

31 M. Stożek, Przemoc $w$ rodzinie. Zapobieganie $w$ świetle przepisów prawa, Warszawa 2009, s. 29. 
szczególnej wagi uznane zostały: polityka zatrudnienia kobiet, zdrowie, świadczenia socjalne, edukacja, równy dostęp do działalności gospodarczej, a także zasobów finansowych i kredytów, ubóstwo kobiet wiejskich, rola mediów w zwalczaniu stereotypowego wizerunku kobiet, zapewnienie kobietom szerszego dostępu do informacji, sytuacja kobiet z rejonów konfliktów zbrojnych, sytuacja kobiet będących jedynymi żywicielami rodziny oraz kobiet fizycznie i psychicznie niepełnosprawnych ${ }^{32}$.

Czwarta Światowa Konferencja w sprawach Kobiet miała miejsce w Pekinie w 1995 r. i była największym spotkaniem międzynarodowym dotyczącym kobiet, które poświęcone zostało dyskryminacji, równości i uwłasnowolnieniu kobiet w skali globalnej, regionalnej, a także w każdym państwie. Dokumentem końcowym tej Konferencji jest tzw. Platforma Działania, w której zostały wskazane cele strategiczne działań w obszarze przeciwdziałania przemocy w rodzinie, do podjęcia których zobowiązane zostały poszczególne państwa ${ }^{33}$.

Spotkania w sprawach kobiet na forum ONZ - Pekin +5 oraz Pekin +10 - od czasu Czwartej Światowej Konferencji w sprawach Kobiet organizowane są w Nowym Jorku co pięć lat specjalne sesje Zgromadzenia Ogólnego, których celem jest monitorowanie procesu wdrażania Platformy Działania. W marcu 2010 roku odbyła się trzecia konferencja, będąca kontynuacją konferencji pekińskich ${ }^{34}$. W czasie tego spotkania dokonana została ocena postępu we wdrażaniu postanowień Deklaracji Pekińskiej i Platformy Działania, a także podsumowanie wyników XXIII Specjalnej Sesji Zgromadzenia Ogólnego ONZ w 2000 roku, której tematem było równouprawnienie kobiet i mężczyzn. Komisja przyjęła także program pracy na lata 2010-2014. Na obrady Komisji do Nowego Jorku przyjechało ponad 3500 reprezentantów organizacji pozarządowych, przedstawiciele rządów, sektora prywatnego i systemu Narodów Zjednoczonych ${ }^{35}$.

Obrady na kolejnej konferencji w Pekinie - Pekin +15 - pokazały, że sytuacja kobiet ulega zmianom, ale nadal we Wspólnocie moż-

32 Postęp dla wszystkich...

33 E. Majewska, Przemoc wobec kobiet $w$ rodzinie i relacjach intymnych. Podstawowe informacje, Warszawa 2005, s. 20-23.

${ }^{34}$ Postęp dla wszystkich...

35 Dane za stroną internetową: http://www.unic.un.org.pl/rownouprawnienie/konf pekin+15.php (dostęp: 15.01.2016). 
na się spotkać z dysproporcją sytuacji kobiet i mężczyzn. Referenci w szczególności akcentowali segregację płciową na rynku pracy — zarówno horyzontalną jak i wertykalną. Różnice w wynagrodzeniach kobiet i mężczyzn nie malały, a w niektórych krajach wręcz rosły. Niemalże wszystkie kraje wskazały jako priorytet aktywizację kobiet na wsi, a także kwestie godzenia życia rodzinnego z życiem zawodowym, promując m.in. urlopy ojcowskie i zachęcając ojców do większego udziału w życiu i wychowaniu dzieci. Zgodnie z raportem, pomimo wzrostu zatrudnienia kobiety wciąż obarczone były większością obowiązków domowych i rodzinnych ${ }^{36}$.

\section{Ochrona praw kobiet w systemie Rady Europy}

Rada Europy powstała w roku 1949. Uchwalony w dniu 5 maja 1949 r. w Londynie Statut Rady Europy w preambule stwierdza, że państwa-sygnatariusze są niewzruszenie przywiązane do wartości moralnych i duchowych, które stanowią wspólne dziedzictwo ich narodów i leżą u podstaw wolności jednostki, wolności politycznej i prymatu prawa, na których opiera się każda prawdziwa demokracja ${ }^{37}$.

Do najważniejszych dokumentów w systemie Rady Europy, których zastosowanie może mieć miejsce $\mathrm{w}$ sprawach związanych z przemocą w rodzinie, zaliczyć należy Europejską Konwencję Praw Człowieka, Europejską Kartę Społeczną, Europejską Konwencję o zapobieganiu torturom oraz nieludzkiemu lub poniżającemu traktowaniu albo karaniu oraz Konwencję Rady Europy w sprawie zapobiegania i zwalczania przemocy wobec kobiet i przemocy domowej. Europejska Konwencja Praw Człowieka $^{38}$ została podpisana w Rzymie 4 listopada 1950 roku, a weszła w życie 3 września 1953 roku. Preambuła stanowi, że deklaracja zmierza do zapewnienia powszechnego i efektywnego stosowania zawartych w niej praw, zaś celem Rady Europy jest osiagnięcie większej jedności

36 15-lecie Pekińskiej Platformy Działania, Departament ds. Kobiet, Rodziny i Przeciwdziałania Dyskryminacji Ministerstwo Pracy i Polityki Społecznej, Warszawa 2010, s. $32-33$.

37 J. Hołda et al., Prawa człowieka, zarys wykładu, Warszawa 2004, s. 68-69.

38 Konwencja o ochronie praw człowieka i podstawowych wolności z dnia 4 listopada 1950 r. (Dz.U. z 1993 r. Nr 61, poz. 284 z późn. zm.). 
jej członków i że jednym ze sposobów osiągnięcia tego celu jest ochrona oraz rozwój praw człowieka i podstawowych wolności ${ }^{39}$. Konwencja tworzyła pierwotnie dwa organy, których zadaniem było kontrolowanie przestrzegania jej postanowień. Była to Europejska Komisja Praw Człowieka i Europejski Trybunał Praw Człowieka. Siedzibą tych instytucji był Strasburg. Po zmianach, jakie nastapiły na przestrzeni lat, utworzony został jeden organ - Europejski Trybunał Praw Człowieka. Orzeka w składzie Komitetów złożonych z 3 sędziów, Izb złożonych z 7 sędziów oraz Wielkiej Izby złożonej z 17 sędziów. Postępowanie przed Trybunałem toczy się na podstawie skargi — państwowej bądź indywidualnej. Formalnie wyrok jest wiążący dla państwa, które było stroną postępowania, jednakże faktycznie wyroki Trybunału uwzględniane są również przez inne państwa zarówno $\mathrm{w}$ trakcie ustanawiania, jak i stosowania prawa $^{40}$.

W Polsce nad implementacją wyroków Europejskiego Trybunału Praw Człowieka do porządku prawnego czuwa międzyresortowy Zespół ds. Europejskiego Trybunału Praw Człowieka. Przewodniczącym tego organu jest Pełnomocnik Ministra Spraw Zagranicznych do spraw postępowań przed Europejskim Trybunałem Praw Człowieka. Jego głównym zadaniem jest wypracowywanie propozycji stanowisk Rządu w odniesieniu do wydawanych przez Trybunał wyroków w sprawach przeciwko Polsce ${ }^{41}$. Podkreślenia wymaga fakt, że orzecznictwo Europejskiego Trybunału Praw Człowieka w zasadzie nie zawiera spraw, które są bezpośrednio związane z przemocą w rodzinie. Jedynymi orzeczeniami, które łączyć można z tym zagadnieniem, są niektóre orzeczenia dotyczące zakazu kontaktu rodziny z dzieckiem ${ }^{42}$ - jak chociażby wyrok w sprawie X\&Y przeciwko Austrii z 1962 roku (decyzja z 8 maja 1962 roku,

39 Preambuła Konwencji o ochronie praw człowieka i podstawowych wolności $\mathrm{z}$ dnia 4 listopada $1950 \mathrm{r}$.

40 J. Hołda et al., op. cit., s. 69-74.

41 M. Stożek, op. cit., s. 41-43.

42 Informacje uzyskane w osobistej rozmowie z przedstawicielem Biura Pełnomocnika ds. Postępowań przed Międzynarodowymi Organami Ochrony Praw Człowieka Ministerstwa Spraw Zagranicznych. 
skarga nr 900/60), w którym Trybunał uznał za zgodne z Konwencją zabronienie kontaktu z dziećmi ojcu, który się nad nimi znęcał ${ }^{43}$.

Europejski Trybunał Praw Człowieka po raz pierwszy wyraźnie zabrał głos w sprawach dotyczących przemocy domowej w sprawie ze skargi Nahide Opuz przeciwko Turcji ${ }^{44}$. W latach 1995-2002 Nahide Opuz i jej matka były maltretowane przez męża Nahide. Ona sama wielokrotnie składała zawiadomienia o popełnieniu przestępstwa w tureckiej prokuraturze, ale wycofywała zeznania z lęku, jaki odczuwała w związku z byciem ofiara przemocy domowej. Gdy po kolejnej kłótni domowej, zakończonej skazaniem męża na karę grzywny za kilkakrotne ugodzenie jej nożem, skarżąca próbowała odejść od niego i zamieszkać ze swoją matką, mężczyzna zastrzelił teściową. Mimo skazania za zabójstwo i nielegalne posiadanie broni w pierwszej instancji na karę 15 lat i 10 miesięcy pozbawienia wolności, sąd zarządził zwolnienie mężczyzny $\mathrm{z}$ aresztu $\mathrm{z}$ uwagi na okres jego pobytu w areszcie oraz fakt wniesienia apelacji. W obawie przed zemstą Nahide Opuz występowała do prokuratury z wnioskami o zapewnienie jej środków ochrony, jednakże organy ścigania nie podjęły stosownych działań w tym zakresie. Rozstrzygając sprawę, ETPC stwierdził naruszenie art. 2 Konwencji (prawo do życia w związku ze śmiercią matki skarżącej) oraz art. 3 Konwencji (zakaz okrutnego traktowania w związku z brakiem reakcji organów ścigania na przemoc domową). Jednocześnie w opinii Trybunału sytuacja, w której kobiety ofiary przemocy domowej, spotyka niewystarczająca ochrona państwa może być poczytywana jako dyskryminacja ze względu na płeć (art. 14 Konwencji). W wyroku Trybunał zaakcentował potrzebę ścigania sprawców przemocy domowej w interesie publicznym oraz konieczność współpracy organów ścigania m.in. z organami opieki socjalnej, a także wymóg odpowiedniej reakcji służb, wyrażającej się w skutecznej i efektywnej pomocy ofiarom przemocy domowej, do czego obliguje je odpowiedni tryb ścigania przestępstw danego rodzaju ${ }^{45}$.

43 M. Stożek, op. cit., s. 41.

44 Wyrok Europejskiego Trybunału Praw Człowieka z dnia 9 września 2009 r., sygn. 33401/02.

45 M. Drewicz, Glosa do wyroku ETPCz z dnia 9 czerwca 2009 r. (skarga nr 33401/02), „Przegląd Sejmowy” 2010, rok XVIII, nr 3 (98), s. 167-170. 
Drugim ważnym dokumentem w systemie Rady Europy, który może mieć zastosowanie w sprawach związanych z przemocą w rodzinie, jest Europejska Karta Społeczna ${ }^{46}$. Do kwestii przemocy w rodzinie odnosi się w sposób pośredni. Umawiające się strony przyjęły za cel swojej polityki, która ma być realizowana za pomocą wszelkich odpowiednich środków, zarówno o charakterze krajowym, jak i międzynarodowym, stworzenie warunków, w których prawo dzieci i młodocianych do szczególnej ochrony przed zagrożeniami fizycznymi i moralnymi, na które są narażeni, będzie mogło być skutecznie realizowane ${ }^{47}$.

W odniesieniu do przemocy wobec dzieci odnotować należy, że w czerwcu 2004 roku Zgromadzenie Parlamentarne Rady Europy przyjęło Zalecenie do Ogólnoeuropejskiego Zakazu Stosowania Kar Fizycznych Wobec Dzieci ${ }^{48}$. W roku 2006 Zgromadzenie Parlamentarne Rady Europy przyjęło Rezolucję 1512 (2006) wzywającą do jedności parlamentarnej w zwalczaniu przemocy domowej, apelując do parlamentów poszczególnych państw o wszczęcie działań na rzecz poprawy sytuacji ofiar przemocy w rodzinie, a także wskazując potrzeby związane z uwzględnieniem działań koordynujących, badań oraz finansowania.

Najnowszym aktem prawa międzynarodowego, którego celem jest zwalczanie przemocy, w tym przemocy domowej, jest Konwencja Rady Europy w sprawie zapobiegania i zwalczania przemocy wobec kobiet i przemocy domowej ${ }^{49}$. W początkowej fazie pracy nad Konwencją odbył się 16-17 maja 2005 r. w Warszawie Szczyt Szefów Państw i Rządów 46 państw członkowskich Rady Europy. Na Szczycie tym przyjęta została deklaracja, w której m.in. zwrócono uwagę na potrzebę przeciwdziałania przemocy wobec kobiet, $\mathrm{w}$ tym również przemocy ze strony członków rodziny. W celu przygotowania odpowiedniej konwencji został powołany Komitet ad hoc CAVAHIO. Komitet spotykał się 9 razy,

46 Europejska Karta Społeczna z dnia 18 października 1961 r. (Dz.U. z 1999 r. Nr 8, poz. 67).

47 Ustęp wprowadzający część I Europejskiej Karty Społecznej.

48 Zalecenie Zgromadzenia Parlamentarnego nr R1666 (2004), przyjęte 24 czerwca 2004 r.

49 Konwencja Rady Europy w sprawie zapobiegania i zwalczania przemocy wobec kobiet i przemocy domowej została sporządzona w Stambule 11 maja 2011 roku. Polska podpisała Konwencję 18 grudnia 2012 roku. 
a wynikiem jego prac był projekt Konwencji Rady Europy w sprawie zapobiegania i zwalczania przemocy wobec kobiet i przemocy domowej. Konwencja została przyjęta przez Komitet Ministrów Rady Europy w Istambule w maju 2011 r. ${ }^{50}$

Jako główne cele uregulowań Konwencja wskazuje w szczególności ochronę kobiet przed wszelkimi formami przemocy oraz zapobieganie, ściganie sądowne i eliminowanie przemocy wobec kobiet i przemocy domowej, promowanie faktycznej równości między kobietami i mężczyznami, opracowanie polityk i środków, których celem będzie udzielenie ochrony i pomocy wszelkim ofiarom przemocy wobec kobiet i przemocy domowej, promowanie międzynarodowej współpracy z myślą o eliminacji przemocy wobec kobiet i przemocy domowej ${ }^{51}$. Państwa-strony Konwencji mają obowiązek zapobiegać występowaniu przemocy wobec kobiet w szczególności poprzez podnoszenie świadomości społecznej, edukację, szkolenia profesjonalistów, podejmowanie interwencji i wprowadzanie programów terapeutycznych. Państwa-strony mają obowiązek zapewnić kobietom doświadczającym przemocy wszelkich form ochrony i pomocy. Państwa-strony są zobowiązane do zapewnienia kobietom doświadczającym przemocy specjalistycznych usług wsparcia, łatwego dostępu do schronisk i całodobowych, bezpłatnych telefonów zaufania ${ }^{52}$. W świetle przepisów Konwencji Polska zobowiązana jest do przeglądu obowiązujących przepisów prawnych tak, aby w pełni odpowiadały one celom podpisanego aktu międzynarodowego. Podkreślenia wymaga fakt, że podpisanie omawianej Konwencji budziło kontrowersje, a przedstawiciele wielu środowisk podejmowali działania mające na celu niedopuszczenie do jej podpisania. Uchwałę popierającą ratyfikację przez Polskę Konwencji przegłosowała Parlamentarna Grupa Kobiet — za było 90\% głosujących. Tym samym odrzucone zostały argumenty ministra sprawiedliwości Jarosława Gowina, że konwencja otwiera drogę do legalizacji małżeństw

50 H. Kłębicka, Konwencja Rady Europy w sprawie zapobiegania i zwalczania przemocy wobec kobiet i przemocy domowej jako nowy instrument w polityce prewencyjnej, „Niebieska Linia” 2011, nr 6.

51 Art. 1 Konwencji Rady Europy w sprawie zapobiegania i zwalczania przemocy wobec kobiet i przemocy domowej.

52 Na podstawie analizy zapisów Konwencji Rady Europy w sprawie zapobiegania i zwalczania przemocy wobec kobiet i przemocy domowej. 
homoseksualnych i że walczy z tradycyjnym modelem małżeństwa i macierzyństwa. Za ratyfikacją opowiedziała się minister sportu Joanna Mucha i ówczesna pełnomocniczka ds. równego traktowania Agnieszka Kozłowska-Rajewicz, która w liście otwartym wyjaśniała, że konwencja ma za zadanie między innymi walczyć ze stereotypami (że kobiety są gorsze, głupsze), bo te stereotypy leżą u podłoża przemocy wobec kobiet ${ }^{53}$. W Uchwale w sprawie udzielenia zgody na podpisanie Konwencji wyraźnie zostało podkreślone, że Polska wprowadziła rozwiązania prawne zapobiegające i zwalczające przemoc wobec kobiet i przemoc domowa (w szczególności w ustawie o przeciwdziałaniu przemocy w rodzinie, prawie karnym, prawie cywilnym oraz w regulacjach prawnych dotyczących pomocy społecznej, ochrony zdrowia). Realizowane są również programy i projekty, których celem jest przeciwdziałanie przemocy w rodzinie, jak Krajowy Program Przeciwdziałania Przemocy w Rodzinie, Rządowy program ograniczania przestępczości i aspołecznych zachowań „Razem bezpieczniej” oraz Krajowy plan działań przeciwko handlowi ludźmi. Dzięki tym działaniom zmniejszyła się skala zjawiska przemocy w rodzinie ${ }^{54}$.

Polska złożyła dwa zastrzeżenia do Konwencji. Pierwsze do artykułu 30 (ust. 2) dotyczącego odszkodowań od państwa, których mogą żądać ofiary przemocy. Polska zastrzega, że będzie stosować ten artykuł wyłącznie w stosunku do pokrzywdzonych obywateli Polski lub Unii Europejskiej oraz „w trybie własnego prawa krajowego”, czyli zgodnie z własnym, wewnętrznym porządkiem prawnym. Drugie zastrzeżenie dotyczy natomiast art. 44 ust. 1 lit. e - stanowi, że Polska zastrzega, iż nie będzie stosować postanowień konwencji w przypadku, kiedy przestępstwo popełnione zostało przez osobę z miejscem stałego zamieszkania na terytorium Polski, ale nie będącą obywatelem państwa polskiego. Po podpisaniu dokumentu swój sprzeciw wyrazili także biskupi z Prezydium Konferencji Episkopatu Polski, uznając, że Konwencja, choć jest poświęcona istotnemu problemowi, to jej podbudowę stanowią założenia

53 Knysz, Kobiety nie uległy Gowinowi, wydanie internetowe „Gazety Wyborczej” z dnia 28 czerwca 2012 r., dane za stroną internetową: http://wyborcza.pl/1,76842,12027803,Kobiety_ nie_ulegly_Gowinowi.html\#TRrelSST (dostęp: 17.12.2015).

54 Jako dowód wskazywany jest spadek ilości skazań w Sądach Rejonowych z art. 207 kodeksu karnego, który obrazują dane statystyczne Ministerstwa Sprawiedliwości z roku 2013 w stosunku do danych z lat ubiegłych. 
ideologiczne, niezgodne z prawdą w założeniach, że przemoc wobec kobiet jest systemowa, a jej źródłem są religia, tradycja i kultura. Konferencja Episkopatu Polski uznała, że Konwencja całkowicie pomija naturalne biologiczne różnice pomiędzy kobietą i mężczyzną oraz zakłada, że płeć można wybierać. Szczególny niepokój Episkopatu wzbudza „łączenie słusznej zasady przeciwdziałania przemocy z próbą niebezpiecznej ingerencji w system wychowawczy i wyznawane przez miliony rodziców w Polsce wartości" ${ }^{55}$. Sprzeciw ten stanowi sygnał, że Kościół w Polsce z dużą ostrożnością, a nawet niechęcią podchodzi do zmian w kwestii sprawowania ról społecznych i rodzinnych, upatrując w tym upadku dawno ustalonego systemu wartości. Takie radykalne stanowisko może tworzyć przeszkodę w tworzeniu systemu ochrony osób doświadczających przemocy w rodzinie w Polsce i pogłębia już istniejące stereotypy.

Ostatecznie Konwencja o zapobieganiu i przeciwdziałaniu przemocy wobec kobiet i przemocy domowej została ratyfikowana przez Prezydenta RP Bronisława Komorowskiego w dniu 13 kwietnia 2015 roku.

Na dzień 13 kwietnia 2015 roku Konwencję podpisało 37 z 47 państw Rady Europy, w tym 23 z 28 należących do UE. Ratyfikowało ją 17 krajów, w tym 10 członków UE ${ }^{56}$.

Przeciwnicy Konwencji wskazują, iż kontrowersyjne jest założenie konwencji, zgodnie z którym przemoc wobec kobiet to skutek nierównych stosunków władzy pomiędzy kobietami a mężczyznami, warunkowanymi na przestrzeni wieków przypisywaniem kobietom i mężczyznom specyficznych ról społecznych. Założenia te prowadzą do wniosku, że tak długo jak będzie istniało zróżnicowanie pomiędzy kobietami i mężczyznami, będzie też istniała przemoc wobec kobiet. Jako wątpliwa wskazywana jest też zgodność przepisów Konwencji z Konstytucja, w szczególności mowa tu o art. 25 ust 2 Konstytucji w związku z art. 13; art 48 ust 1; art. 18; art. 32 i art. 33 oraz art. 42 ust 2 i art. 2 w związku

55 Toch, Ostry sprzeciw polskich biskupów po podpisaniu konwencji o zapobieganiu przemocy wobec kobiet, wydanie internetowe „Gazety Wyborczej” z dnia 18 grudnia 2012 r., dane za stroną internetową: http://wyborcza.pl/1,75478,13069943,Ostry_sprzeciw_polskich_biskupow_po_podpisaniu_konwencji.html\#ixzz2YIlRebuq (dostęp: 17.12.2015).

56 http://www.bankier.pl/wiadomosc/Prezydent-ratyfikowal-konwencje-antyprzemocowa-3321782.html (dostęp: 17.12.2015). 
z art. 45 ust. 1 Konstytucji. Przeciwnicy Konwencji wskazują również na wattpliwość co do zgodności tego aktu prawnego z zasadą bezstronności światopoglądowej państwa oraz podkreślają ingerencję w prawo rodziców do wychowania swych dzieci zgodnie z własnymi przekonaniami, chronione konstytucyjnie ${ }^{57}$. Mimo wielu kontrowersji niewattpliwie ratyfikowanie Konwencji jest krokiem we właściwym kierunku. Sposób wprowadzenia jej przepisów w polski porządek prawny pokaże, czy założenia tego dokumentu zostały w pełni zrealizowane.

\section{Unia Europejska a prawa kobiet i zjawisko przemocy w rodzinie}

Zgodnie z orzecznictwem Europejskiego Trybunału Sprawiedliwości UE, a także traktatami, Unia Europejska nie posiada ogólnych uprawnień $\mathrm{w}$ kwestii praw podstawowych — $\mathrm{w}$ tym praw dzieci i kobiet. Zgodnie z art. 6 ust. 2 Traktatu o Unii Europejskiej ${ }^{58}$ UE szanuje prawa podstawowe w każdym $\mathrm{z}$ działań, jakie podejmuje stosownie do swoich kompetencji. Jednym z najważniejszych dokumentów unijnych, które odnoszą się do praw człowieka, jest Karta Praw Podstawowych ${ }^{59}$, przyjęta na szczycie w Nicei w 2001 roku. Zadaniem tego dokumentu jest umocnienie konstytucyjnego charakteru traktatów, rozszerzenie i skonsolidowanie praw podstawowych deklarowanych we wcześniejszych dokumentach i orzecznictwie ETS. Jako inne znaczenie Karty wskazywana jest zmiana postrzegania Unii Europejskiej na arenie światowej jako nie tylko organizacji gospodarczej, ale również organizacji, w której ochrona praw człowieka ma ważne znaczenie ${ }^{60}$.

57 Czy Polska powinna ratyfikować Konwencje Rady Europy o zapobieganiu i przeciwdziataniu przemocy wobec kobiet i przemocy domowej?, red. D. Bach-Golecka et al., I. Raport Instytutu Ordo Iuris, Instytut Na Rzecz Kultury Prawnej, Warszawa 2014, s. 4-15.

58 Traktat o Unii Europejskiej z 07.02.1992 r. (Dz.U. z 2004 r. Nr 90, poz. 864/30 z późn. zm.).

59 Karta Praw Podstawowych Unii Europejskiej (2007/C 303/01), Dz. Urz. UE z 14.12.2007 r., C 303/1.

60 J. Hołda et al., op. cit., s. 88-89. 
Unia Europejska zdecydowanie zareagowała na przemoc domowa, która rozumiana była jako przemoc wobec kobiety ze strony partnera. W roku 1997 Europejskie Lobby Kobiet stworzyło inicjatywę European Policy Action Centre oraz Observatory on Violence against Women ${ }^{61}$. W styczniu 1999 roku Komisja Europejska rozpoczęła ogólnoeuropejską kampanię przeciwko przemocy domowej. Dzięki niej wzrosła świadomość społeczna i zrozumienie zagadnienia przemocy w rodzinie. W maju 2006 roku Europejski Komitet Społeczno-Gospodarczy wydał opinię nr 2006/C 110/15 wzywającą ponownie do skupienia się na tematyce przemocy domowej i stworzenia wspólnej, europejskiej strategii. Komitet wezwał szczególnie do badań w skali europejskiej, mających na celu określenie powszechności zjawiska przemocy domowej, wpływu przemocy domowej na jednostkę oraz na całe społeczeństwo, a także związanych z nim kosztów finansowych ${ }^{62}$. Jednym z szerszych działań Unii w kwestii przemocy w rodzinie była kampania zero tolerancji dla przemocy wobec kobiet (prowadzona przez Komisję Europejską w latach 1999/2000). Kampania ta była odpowiedzią na rezolucję Parlamentu Europejskiego na temat potrzeby zorganizowania tego typu przedsięwzięcia. W marcu 1999 roku w Kolonii miało miejsce międzyministerialne spotkanie dotyczące przemocy wobec kobiet, a końcowa konferencja odbyła się w Lizbonie w maju 2000 roku. W trakcie kampanii i konferencji ustalono, że przemoc domowa istnieje we wszystkich krajach Unii i we wszystkich klasach społecznych. Komisja sformułowała komunikaty dla różnych grup docelowych, w tym m.in.:

- dla sprawców przemocy:

- przemoc domowa jest przestępstwem;

- przemoc domowa zrujnuje życie sprawcy tak samo, jak życie jego ofiary;

61 Jest to międzynarodowa organizacja non-profit, która podejmuje działania na rzecz równości kobiet i mężczyzn oraz eliminacji wszelkich form przemocy wobec kobiet. Więcej na http://www.womenlobby.org/?lang=en.

62 Broszury Daphne: Problemy i doświadczenia zwiqzane ze zwalczaniem przemocy wobec dzieci, młodzieży i kobiet. Przemoc w rodzinie. Kane J. we współpracy z zespołem odpowiedzialnym za Program Daphne Komisji Europejskiej, Komisja Europejska, DG ds. Sprawiedliwości, Wolności i Bezpieczeństwa. Program Daphne, B-1049 BrukselaBelgia, lipiec 2008. 
— jeśli sprawca chce zaprzestać stosowania przemocy, może zwrócić się o pomoc;

- dla ofiar przemocy:

— należy przełamać mur milczenia otaczający przemoc domową;

— nie należy tolerować istniejącej przemocy;

— należy dowiedzieć się jak uzyskać pomoc;

- dla świadków przemocy: czenie;

— trzeba pomóc kobietom — ofiarom przemocy — przełamać mil-

- trzeba pomóc im uniknąć wiktymizacji ${ }^{63}$.

Rok 2007 został uznany przez Unię Europejską za rok walki z przemocą wobec kobiet. Jego inauguracja odbyła się w Madrycie 27 listopada 2006 roku poprzez kampanię społeczną, której celem było przyczynienie się do upowszechnienia podejścia do przemocy wobec kobiet jako naruszania praw człowieka, a także uświadomienie, że istnieje nie tylko przemoc fizyczna, ale także psychiczna, ekonomiczna i seksualna. Dążeniem twórców kampanii było zachęcanie państw członkowskich do aktywniejszego wdrażania środków prawnych oraz programów, które umożliwiłyby skuteczniejsze przeciwdziałanie przemocy ${ }^{64}$.

Najważniejszą inicjatywą Unii w odniesieniu do problemu przemocy w rodzinie jest program Daphne, zapoczątkowany w 1997 roku jako element reakcji KE na wzrastające zaniepokojenie związane z przemocą wobec dzieci, młodzieży i kobiet w Europie. Program trwał trzy lata, a jego budżet na ten okres wynosił 11 milionów euro. W związku z sukcesem inicjatywy i ogromnym zainteresowaniem ze strony państw członkowskich KE w 2000 roku zatwierdziła i rozpoczęła czteroletni Program Daphne (2000-2003) z budżetem 20 milionów euro na lata 2000-2003. W roku 2003 Komisja zaproponowała kontynuowanie akcji, co spotkało się z pozytywnym przyjęciem przez społeczność międzynarodową. Tym samym Parlament Europejski i Rada zatwierdziły nowy program - Daphne II — na okres 2004-2008, z budżetem 50 milionów euro. Ogólnym celem Daphne II była walka z przemocą wobec dzieci, młodzieży i kobiet, a także wspieranie i ochrona ofiar i grup ryzyka. Przemoc-

63 M. Stożek, op. cit., s. 51-52.

64 Rada Europy $w$ walce $z$ przemoca wobec kobiet. Przemoc wobec kobiet zagrożeniem dla podstawowych wartości Europy, „Prawo i Płeć” 2008, nr 9, s. 19. 
zarówno fizyczna, jak i psychiczna - rozumiana była bardzo szeroko. Za przemoc uznawano wykorzystywanie seksualne, przemoc w rodzinie, wykorzystywanie seksualne w celach zarobkowych, nękanie słabszych w szkołach, handel ludźmi, a także przemoc wynikającą z dyskryminacji i skierowaną przeciwko niepełnosprawnym, mniejszościom, migrantom i innym grupom na nią narażonym. Program ten uznawał przemoc za przestępstwo. Co roku ustalane były roczne priorytety, które można znaleźć na stronie internetowej Daphne oraz w corocznym „Wezwaniu do składania propozycji” (ang. call for proposals). W okresie od 1997 do 2004 fundusze Daphne otrzymało 361 projektów ${ }^{65}$.

Kolejna edycja programu — Program Daphne III pod hasłem „Zapobieganie i zwalczanie przemocy wobec dzieci, młodzieży i kobiet oraz ochrona ofiar i grup ryzyka" jako program szczegółowy Unii Europejskiej na lata 2007 - 2013 został przyjęty przez Parlament Europejski i Radę Unii Europejskiej w dniu 20 czerwca 2007 roku (wszedł w życie w dniu 7 lipca 2007 roku po jego publikacji w Dzienniku Urzędowym UE). Projekt jest częścią programu „Prawa Podstawowe i Sprawiedliwość".

Adresatami programu są wszystkie grupy, bezpośrednio lub pośrednio zajmujące się zjawiskiem przemocy. Jednym z podstawowych elementów programu Daphne III jest wspieranie podmiotów realizujących cele programu w zakresie zapobiegania i zwalczania przemocy wobec dzieci, młodzieży i kobiet oraz pomocy ofiarom m.in. poprzez:

- udzielanie dotacji operacyjnych - tzw. operation grants - dla organizacji pozarządowych (zgodnie z warunkami określanymi przez KE);

- $\quad$ udzielanie dotacji na konkretne projekty ponadnarodowe leżące w interesie UE - tzw. action grants — przedstawione przez podmioty z co najmniej dwóch państw członkowskich (m.in.

65 Program Daphne II 2004-2008 na rzecz zapobiegania i zwalczania przemocy wobec dzieci, młodzieży i kobiet oraz ochrony ofiar i grup ryzyka. Przewodnik po operacyjnym, administracyjnym i finansowym zarządzaniu projektem Daphne II 2006-1, Komisja Europejska, DG ds. Sprawiedliwości, Wolności i Bezpieczeństwa, Dyrektoriat C: Sprawiedliwość społeczna, prawa i obywatelstwo, Jednostka C4: Finansowe wsparcie sprawiedliwości, praw i obywatelstwa, s. 3-4. 
przez organizacje pozarządowe, władze lokalne na właściwym poziomie, lokalne jednostki służb bezpieczeństwa i porządku publicznego, ośrodki naukowe i badawcze etc.).

Na poziomie krajowym wdrażanie Programu ,Zapobieganie i zwalczanie przemocy wobec dzieci, młodzieży i kobiet oraz ochrona ofiar i grup ryzyka - DAPHNE III na lata 2007-2013" wspomaga Ministerstwo Spraw Wewnętrznych i Administracji ${ }^{66}$.

Zalecenia dla Unii Europejskiej w odniesieniu do ochrony ofiar przemocy $\mathrm{w}$ rodzinie są następujące. Po pierwsze UE powinna podjąć wszelkie niezbędne środki w celu rozwiązania i likwidacji wszelkich form przemocy wobec kobiet jako nieodłączną część strategii, polityk i działań w zakresie równości płci. W szczególności powinno się stworzyć w ramach obecnej struktury UE podstawę prawną do zapewnienia, że wszelkie formy przemocy wobec kobiet będą rozwiązywane za pomocą szerokich i feministycznych definicji przemocy mężczyzn wobec kobiet. Należałoby również przedstawić dyrektywy w sprawie przemocy wobec kobiet, której zadaniem będzie zapewnienie ochrony i pomocy dla kobiet oraz kary dla sprawców przemocy. Powinien być również opracowany europejski plan działania w sprawie przemocy wobec kobiet, o szczególnym finansowaniu.

Po drugie UE powinna zapewnić stały i systematyczny monitoring pomiaru postępów w odniesieniu do zwalczania wszelkich form przemocy wobec kobiet. Ostatnim zaleceniem jest zapobieganie i ochrona kobiet - ofiar handlu ludźmi w celu wykorzystywania seksualnego, a także ściganie kupujących i czerpiących dochody z nierządu i prostytucji ${ }^{67}$.

Początkowo o pozycji ofiary $\mathrm{w}$ postępowaniu karnym stanowiła Decyzja Ramowa Rady Unii Europejskiej z 15 marca 2001 roku $^{68}$. Dokument ten zawierał definicje pojęć: „ofiara, „organizacja udzielająca wsparcia”, ,,postępowanie karne”, ,postępowanie”, „mediacje w spra-

66 Materiały informacyjne o programie Daphne III - Ministerstwo Spraw Wewnętrznych i Administracji, Departament Bezpieczeństwa Publicznego.

67 Materiały informacyjne Międzynarodowej Konferencji pod patronatem Izabeli Jarugi-Nowackiej na temat: Rozwiazywanie problemów przemocy z perspektywy europejskiej, która odbyła się w Warszawie w dniu 8 grudnia 2009 r.

68 Decyzja Ramowa Rady Unii Europejskiej z dnia 15 marca 2001 r. o pozycji ofiary w postępowaniu karnym (2001/220/WSiSW), Dz.Urz. UE z 22 marca 2001 r., L82/1. 
wach karnych". Dokument ten zalecał państwom członkowskim wprowadzenie do krajowych ustawodawstw regulacji, które zapewnią ofiarom prawo do szacunku i uznania, wypowiedzenia się i przedstawienia dowodów, uzyskania informacji, ochrony, uzyskania kompensacji w trakcie postępowania karnego oraz dających gwarancję w zakresie komunikowania się, zapewniających wsparcie ofiary, zwrotu wydatków związanych z uczestnictwem w postępowaniu karnym, mediacji oraz właściwej pomocy i zadośćuczynienia ofiarom z innych państw członkowskich. Decyzja podkreślała konieczność szczególnego traktowania grup ofiar, które z uwagi na różne okoliczności wymagają szczególnej troski — w tym dzieci; wskazała też państwom członkowskim kierunek harmonizacji prawa w zakresie ochrony ofiar przestępstwa, a jego celem jest zdecydowana poprawa ich sytuacji ${ }^{69}$. Decyzja ta została zastapiona dyrektywą Parlamentu Europejskiego i Rady 2012/29/UE z dnia 25 października 2012 r. ustanawiająca normy minimalne w zakresie praw, wsparcia i ochrony ofiar przestępstw ${ }^{70}$. Według przepisów tej Dyrektywy należy uznać za ofiarę osobę poszkodowaną niezależnie od tego, czy sprawca został zidentyfikowany, schwytany, oskarżony lub skazany, a także niezależnie od więzi rodzinnych łączących sprawcę z tą osobą. Art. 3 Dyrektywy zapewnia ofiarom prawo do rozumienia i bycia rozumianym od pierwszego momentu kontaktu ze służbami aż do rozstrzygnięcia sprawy, a także później — jeżeli będą tego wymagały okoliczności. Dyrektywa zobowiązuje także Państwa członkowskie do pisemnego potwierdzania złożenia przez ofiarę formalnego zawiadomienia o przestępstwie, kładzie również nacisk na prawo ofiary do unikania kontaktu ze sprawca, ochronę prywatności ${ }^{71}$.

69 M. Sajkowska, J. Szymańska, Międzynarodowe standardy ochrony ofiar przestęstw, „Dziecko Krzywdzone” 2004, nr 6, s. 6-13.

70 Dyrektywa Parlamentu Europejskiego i Rady 2012/29/UE z dnia 25 października 2012 r. ustanawiająca normy minimalne w zakresie praw, wsparcia i ochrony ofiar przestępstw, Dzienniki Unii Europejskiej, Seria L z 14 listopada 2012, s. 57-73.

${ }^{71} \mathrm{Na}$ podstawie analizy treści Dyrektywy Parlamentu Europejskiego i Rady 2012/29/UE z dnia 25 października 2012 r. ustanawiająca normy minimalne w zakresie praw, wsparcia i ochrony ofiar przestępstw. 


\section{Podsumowanie}

Każdy z wymienionych wcześniej systemów prawnych reguluje w inny sposób prawa człowieka. Nie ulega wątpliwości, że ochrona przed przemocą $\mathrm{w}$ rodzinie ma swoje początki w uregulowaniach prawa międzynarodowego. Stamtąd wywodzą się przepisy dotyczące równouprawnienia kobiet i mężczyzn, przepisy o prawie do godności, do życia w bezpiecznych warunkach $i$ wiele innych regulujących prawa i wolności każdej jednostki ludzkiej. Pod względem formalnym prawa człowieka to dziedzina prawa konstytucyjnego i międzynarodowego, której zadaniem jest zinstytucjonalizowana obrona praw każdego człowieka.

\section{The issues of domestic violence in the context of chosen international regulations}

\section{Summary}

In the article the problem of domestic violence in the context of legal regulations relating to the protection of human rights is discussed. Reference was made to the historical origins of activities related to the legal protection of fundamental rights and freedoms. A distinction of women's rights, children and domestic violence in relation to the practice of the United Nations, the Council of Europe and the European Union is considered as a tool to present arguments. The article describes the most important documents regarding the rights of women and children and domestic violence; the rights and duties imposed on signatories in the context of protection of rights and the development of regulations and methods of their implementation referring also to Polish law. The discussion that took place in the public debate prior to ratification of the Convention of the Council of Europe is also touched. The article is an attempt to indicate a significant space they occupy on the issues of domestic violence and their protection in the listed international regulations.

Keywords: domestic violence, international law, legal regulations, fundamental rights, women rights. 